\title{
Happiness and Optimism Interventions at Work: Gender Differences
}

\author{
Alejandro Sanín-Posada', Marisa Salanova Soria² ${ }^{1}$ Pablo Vera-Villaroel ${ }^{3}$ \\ ${ }^{1}$ Centro de Investigación en Comportamiento Organizacional Cincel, Medellín, Colombia \\ ${ }^{2}$ Equipo de Investigación WANT-Prevención Psicosocial y Organizaciones Saludables, Universitat Jaume I, Valencia, Spain \\ ${ }^{3}$ Centro de Innovación en Tecnologías de la Información para Aplicaciones Sociales, Universidad de Santiago de Chile, \\ Santiago, Chile \\ Email: asaninp@cincel.com.co, marisa.salanova@uji.es,pablo.vera@usach.cl
}

How to cite this paper: Sanín-Posada, A., Soria, M.S. and Vera-Villaroel, P. (2018) Happiness and Optimism Interventions at Work: Gender Differences. Open Access Library Journal, 5: e4842. https://doi.org/10.4236/oalib.1104842

Received: August 16, 2018

Accepted: November 27, 2018

Published: November 30, 2018

Copyright $\odot 2018$ by authors and Open Access Library Inc.

This work is licensed under the Creative Commons Attribution International License (CC BY 4.0).

http://creativecommons.org/licenses/by/4.0/

(c) (i) Open Access

\begin{abstract}
The aim of this quasi-experimental study was to analyze the changes derived from happiness and optimism interventions in 12 groups of employees chosen at random in two Colombian companies. For the happiness intervention, three conditions were applied: Expressing Gratitude, Acts of Kindness and Pencil in the Mouth. In the case of optimism, three other conditions were used: Breaking the Routine, Reformulating Goals and Resignifying Failure. In addition, answers from a control group, a placebo group and another group on a waiting list were included. 93 people completed the questionnaires at both Time 1 (before the intervention) and Time 2 (after the intervention). Testing of related samples was performed to verify the changes according to each condition. The results show that the condition of kindness alone and combined with the reformulation of goals tended to have more positive effects on happiness levels. There were differences in the effectiveness associated with gender and the employees' previous levels of happiness and optimism. The practical applications of these findings in the work context and their influence on work performance are discussed.
\end{abstract}

\section{Subject Areas}

Psychology

\section{Keywords}

Intervention, Happiness, Optimism, Gender, Performance

\section{Introduction}

Improving people's well-being and quality of life requires an understanding of 
the background and effects of how people think, feel and act. Years of research have brought important advances, with literature that explains the psychological processes underlying well-being and quality of life. However, the focus on the study of psychological pathology has been to the detriment of the study of optimal functioning [1]. The same is occurring in the field of psychological intervention, particularly in work contexts. However, there has been an increase in research with this approach in the last decade [2] [3] [4] [5].

This trend has been different in Latin America. There are few studies on intervention into positive aspects at work. The last reference about it was found in Calderón, Álvarez \& Naranjo [6]. This does not mean that positive interventions are not conducted at Region, but rather we believe that such a practice is not documented, which may be due to them being conducted at times with no clear idea of the effects they will have or to the difficulty in verifying their effectiveness in organizational contexts. Another obstacle to undertaking such research is the resistance organizations have in giving employees the time to participate [7].

\subsection{Happiness Intervention at Work}

Happiness is understood as a phenomenon that characterizes people who usually feel satisfaction and enjoyment and obtain gratification from what they do in life [8]. This can be general or specific and associated with the person's spheres of action, such as work for example [9]. Happiness at Work is defined the same as the general, only delimiting its dimensions in that context. Like the general, it is susceptible to intervention.

Seligman et al. [1] designed various actions to increase it. They found that describing positive events, exploring one's own strengths and expressing gratitude have long-term effects on happiness. Other authors have found that the activities related to social issues, membership and the search for support also work [10]. On the other hand, the experiments conducted by Abbe, Tkach and Lyubomirsky [11] show that positive changes produce positive emotions that are resistant to the hedonic treadmill and benefit well-being over time. The most effective conditions indicated by these last authors are the expression of gratitude and exhibiting behaviors of goodness and kindness.

Other activities that have been effective in increasing happiness are those of affiliation and participation, mental control, goal-oriented work, actively taking advantage of free time or relaxing, being dedicated to religious activities and generally direct and intentional attempts at achieving happiness [12]. It was also found that asking people to recall three positive events increases it, particularly in those who put more effort into the activity [13]. Of all interventions referred, only the last one was done in a work context, and it was not mentioned whether there were any differences with respect to its effectiveness in terms of gender. Other inventions made in organizations have shown positive effects and that is an incentive to think that it is possible to generate positive changes in the company [14] [15]. 
The conditions related to activities that people do for themselves are more beneficial [3]. The context-dependent ones or the circumstances have little predictive power, and the context-dependent ones can also represent long-term changes in happiness and overcome the effect of the hedonic treadmill [16]. Some circumstances can also have this effect in the long term [17], which suggests that adaptation is not always complete and depends on the circumstance.

Despite knowledge about the conditions for improving happiness, there is little research that reveals if its increase has any effect on people's work performance and productivity [18]. This is only mentioned as a possibility, which leaves open the debate on whether happiness affects work performance or not [19].

This discussion is based on studies that show contradictory and inconclusive results. Some show no relation [20] [21], while others do [22] [23] [24]. It seems, however, that the more interesting question than whether there is a relation or not, is when it occurs and why that is. Some authors suggest that it is due to the relation being mediated by other variables [25]. Others explain the lack of relation by arguing that performance requires motivation and a certain "tension", and satisfaction goes against that, because it usually generates a different emotional state, one of calm, with dissatisfaction then being the one that affects performance [26]. The lack of association may also be following the little uniformity in the measures of either constructs or methodological reasons [20]. For example, it is common to assume the constructs of work satisfaction and happiness at work to be synonyms when, in fact, they are different. The former is an affective reaction resulting from the contrast between reality and the expectations and interests inherent to work [27]. The latter tends toward stability and is considered more a trait.

All this indicates an interesting panorama for the present study. It shows first that it is possible to obtain changes in happiness; second, that these can occur in the long term; and third, it contributes to the debate about whether happiness does indeed benefit performance.

In this study, and considering the literature review, the improvement in happiness was treated with the expression of gratitude, actions of kindness and the pencil in the mouth. The first two are interventions that are social in nature [1] [12] [16]; the last is based on proprioceptive principles [28].

\subsection{Optimism Intervention at Work}

Optimism manifests in the favorable expectations related to the occurrence of upcoming events [29]. It tends to be stable, as it is configured as a system of beliefs [30] [31], which can be supported by objective or subjective information, reliable or not [32] and be general or specific to a particular context, like work for example [33]. In that context optimistic people can expect good results related to what they themselves will be able to achieve or what the team or the company can achieve. 
The concept has been widely investigated and there is information about its background and consequences, but the effects of its intervention have scarcely been documented [34]. However, being a system of beliefs makes it susceptible to intervention. Thanks to the knowledge about its background, some activities can be defined that could increase it [34].

It is known that optimism is facilitated by the possibility of reaching valuable goals. Therefore, a strategy to develop it would be to have people formulate their goals as attainable, challenging and sensible objectives [34]. Additionally, it has been found that when people begin to think more about others than themselves, they are usually more optimistic. Managing to think that their goals respond to a greater purpose beyond themselves could then be useful for reinforcing their optimism. Other findings indicate that those who cope well with failure and accept themselves tend to be more optimistic, which is why helping people to see their failure as a learning element could be useful.

Moreover, there is a known association between optimism and extroversion [32], which raises the question whether its development will lead to motivating people to share with others and be spontaneous.

On this basis, three conditions were designed for the optimism intervention at work: Breaking the Routine, Reformulating Goals, and Resignifying Failure. In addition it was decided to combine some strategies: Reformulating Goals with Kindness, Resignification of Failure with Gratitude and Breaking the Routine with Pencil in Mouth. The mix was random. Each strategy to enhance happiness was paired whit one that increase optimism. This is in order to see if intervention of both at the same time has a different effect.

The conditions for improving happiness and optimism were implemented with the aim of verifying their effectiveness in work contexts. And these were reviewed as to whether they are the same in men and women. Differentiation by gender was done because in several studies it has been reported that the findings in psychology cannot be generalized to men and women [35] [36] [37]. It is possible that the effects are different for this reason and that the practices do not work the same way [38]. Men and women are exposed to different parenting patterns, and on many occasions are treated differently [39]. According to the research, activities that involve social contact, such as breaking routine and kindness, could be more effective for women, because to the importance they attach to contact with others [40]. Reformulation of goals can also be expected to be more effective for them, because women, usually, have double shift, and the possibility to focusing can help them to find sense of what they do [41].

On the other hand, expressing gratitude and resignification of failure could be more effective for men, because their social role prevents them from doing this frequently, as they may appear weak or sentimental in a culture like Colombian [39]. In addition, the development of concrete activities could favor men because the way they usually process the information [40], hence it is expected that the Pencil in the Mouth will be more effective to them. 


\subsection{Hypothesis}

H1: The expression of gratitude will increase happiness, but we expect significant differences depending on gender, with men having the greatest increase compared to women.

$\mathrm{H} 2$ : The behaviors of kindness will increase happiness, but we expect significant differences depending on gender, with women having the greatest increase compared to men.

H3: The pencil in the mouth will increase happiness, but we expect significant differences depending on gender, with men having the greatest increase compared to women.

H4: The Resignification of Failure will increase optimism, but we expect significant differences depending on gender, with men having the greatest increase compared to women.

H5: The Reformulation of Goals will increase optimism, but we expect significant differences depending on gender, with women having the greatest increase compared to men.

H6: Breaking the Routine will increase optimism, but we expect significant differences depending on gender, with women having the greatest increase compared to men.

H7: The combination of conditions will have effects on the happiness and optimism.

\section{Method}

\subsection{Design}

Quasi-experimental study is with pretest and post-test, with equivalent control groups.

\subsection{Participants}

197 people from two companies participed in the study, 58.4\% from company 1 . Ninety-three people completed the assessment at time one and two $52.8 \%$ of mortality). $55.9 \%$ were women, $63.2 \%$ were between 26 and 40 years of age, $14 \%$ were under $26,14 \%$ were over $45 \%$ and $8.8 \%$ were between 41 and $45.70 .2 \%$ had worked for their company less than 8 years.

\subsection{Instruments}

Happiness Scale General and at Work ( $\alpha \geq 0.70$; AFC, CFI and TLI $>0.90$ and $\alpha$ $\geq 0.70$; AFC, CFI and TLI $>0.90$, respectively), adaptations for the Colombian working population from the Authentic Happiness Inventory [33]. They are completed by choosing one of five possible options that describe the person's mood (e.g. A..., B..., C. I am more happy than sad., D..., E...). The same items are answered with life in general in mind first and then in the work context. They evaluate Happiness in Life (H_Life) and Happiness at Work (H_Work). 
Optimism/Pessimism Scale in Life, in the company and at Work ( $\alpha \geq 0.70$; AFC, CFI and TLI > 0.90), adaptation of the LOT-R for the Colombian working population [9]. It has 10 test items that must be completed by thinking about life in general, then in the company and finally at work. Responses are based on a Likert scale with the extremes 4 "Totally agree" and 1 "Totally disagree" (e.g. In difficult times, I tend to hope for the best). They assess Optimism/Pessimism (O_Life/P_Life), Optimism/Pessimism in the company (O_Company/P_Company) and Optimism/Pessimism at Work (O_Work/P_Work).

Satisfaction with Life Scale (S_Life) ( $\alpha \geq 0.70$; AFC, CFI and TLI $>0.90)$ by Pavot and Diener [42]. It has 5 items that are answered on the basis of Likert scale extremes 6 "Totally agree" and 1 "Strongly disagree" (e.g. 3. I am satisfied with my life). It measures the degree to which a person feels satisfied with their life in general.

Performance Rating Scale (PRS). It examines: Intra-role performance (P_Intrarol) ( $\alpha=0.93)$, Extra-role performance (P_Extrarol) $(\alpha=0.85)$ and Compliance with rules (C_Rules) ( $\alpha=0.84)$ [43].

On the Likert scales, the central point of the original scale was eliminated (neither agree nor disagree), as it introduces a value that does not contribute any real information about the level of the variable. The recorded scores are calculated with Colombian scales.

\subsection{Procedure}

The aim and the process were explained in detail to the participants, and their consent was obtained according to the parameters set out by Colombian law. The ethical management conditions were reviewed and guaranteed by the Science Committee of the Cincel Center for Research in Organizational Behavior and by the human resource managers in each company.

In the two companies people who wanted to participate enrolled. These were distributed randomly into 12 groups. Table 1 shows the strategy assigned to each group and the resulting $\mathrm{n}$ after combining the data from the two companies.

The people in the twelve groups had the variables measured before beginning the interventions. Then they were given the corresponding protocol [44], which they had a month to complete. When time was up, the variables were measured again. Monitoring took place three months later. Their respective managers were also asked to participate in the study. The aim was to evaluate the participants' performance as an indicator of the effect of the practices. 36 managers described

Table 1. Groups, conditions applied and n.

\begin{tabular}{|c|c|c|c|c|c|c|c|}
\hline Happiness & $\mathrm{n}$ & Optimism & $\mathrm{n}$ & Combination & $\mathrm{N}$ & Control & $\mathrm{n}$ \\
\hline Pencil in the Mouth & 9 & Resignification of Failure & 11 & Reformulation of Goals/Kindness & 9 & Placebo & 10 \\
\hline Gratitude & 6 & Breaking the Routine & 9 & Resignification of Failure/Gratitude & 7 & Control & 9 \\
\hline Kindness & 6 & Reformulation of Goals & 3 & Breaking Routine/Pencil in the Mouth & 6 & Waiting & 8 \\
\hline
\end{tabular}


their staff's performance at times one and two. Of these only 22 could be matched with the participants' data. The remaining 14 were scores from managers whose employees did not complete the questionnaires at time two.

The participants were asked to refrain from practices that contribute to improving their performance in the task during the month in which they participated in the study to control the effect of the training.

Once the data were collected, the variables were calculated and their normality was verified using the Kolmogorov-Smirnov test. Only intra-role performance at times 1 and 2 showed normality ( $p>0.050)$. As a result of this and for being small groups, the decision was made to use nonparametric statistics. The test of related samples was applied to confirm whether there was any significant change in the level of the variables between times one and two. Due to mortality of the sample, neither data from the third time nor from that evaluated by the managers were analyzed. Although a repeated measures multivariate analysis of variance would have been more robust, it was not possible to apply it given the sample sizes and group distribution. The software SPSS v.21 was used to calculate the statistics. $\mathrm{G}^{\star}$ Power v.3.1 was used to calculate the size of the effect $(\mathrm{dz})$.

\section{Results}

Table 2 presents statistically significant correlations between the positive variables, with the highest being those reported between Happiness at Work, Happiness in Life and Satisfaction with Life. There are negative correlations between the positive aspects and pessimism. None of the performance types correlated with positive effects.

Happiness at Work improved due to application of the strategy of Breaking

Table 2. Means, Standard Deviations (SD) and Correlations between the study variables at time 1 and time 2.

\begin{tabular}{|c|c|c|c|c|c|c|c|c|c|c|c|c|c|c|}
\hline & Mean (SD) 1 & Mean (SD) 2 & 1 & 2 & 3 & 4 & 5 & 6 & 7 & 8 & 9 & 10 & 11 & 12 \\
\hline 1. H_Work & $52.83(9.43)$ & $52.80(9.33)$ & - & $0.664^{\star *}$ & $0.412^{* *}$ & $-0.221^{*}$ & $0.472^{\star *}$ & -0.198 & $0.436^{\star *}$ & -0.146 & $0.582^{\star *}$ & 0.321 & 0.112 & -0.063 \\
\hline 2. H_Life & $52.03(10.74)$ & $53.63(11.14)$ & $0.607^{* *}$ & - & $0.250^{*}$ & -0.190 & 0.195 & -0.205 & $0.528^{\star *}$ & $-0.275^{\star \star}$ & * $0.613^{\star *}$ & 0.052 & 0.013 & 0.181 \\
\hline 3. O_Company & $50.85(9.32)$ & $51.07(9.30)$ & $0.469^{\star *}$ & $0.333^{\star \star}$ & - & -0.099 & $0.669^{\star *}$ & -0.150 & $0.604^{\star *}$ & -0.084 & $0.355^{\star \star}$ & 0.335 & -0.073 & 0.174 \\
\hline 4. P_Company & $47.01(8.78)$ & $45.48(8.07)$ & -0.196 & $-0.260^{\star}$ & -0.169 & - & -0.165 & $0.880^{* *}$ & $-0.236^{\star}$ & $0.726^{\star *}$ & $-0.320^{\star *}$ & 0.173 & 0.032 & 0.249 \\
\hline 5. O_Work & $50.00(10.27)$ & $49.61(10.12)$ & $0.477^{\star *}$ & $0.360^{* *}$ & $0.740^{* *}$ & -0.078 & - & -0.125 & $0.639^{* *}$ & -0.001 & $0.352^{* *}$ & 0.162 & -0.281 & -0.253 \\
\hline 6. P_Work & $47.60(9.44)$ & $45.37(8.27)$ & $-0.297^{\star *}$ & ${ }^{*}-0.301^{\star *}$ & $-0.312^{\star \star}$ & $\star 0.752^{\star *}$ & $-0.346^{\star *}$ & - & $-0.237^{\star}$ & $0.832^{\star *}$ & $-0.323^{\star *}$ & 0.109 & 0.095 & 0.098 \\
\hline 7. O_Life & $50.38(9.34)$ & $50.96(9.40)$ & $0.326^{* *}$ & $0.432^{\star *}$ & $0.542^{* *}$ & -0.080 & $0.725^{\star *}$ & $-0.297^{\star \star}$ & - & $-0.259^{*}$ & $0.528^{* *}$ & 0.093 & -0.252 & 0.057 \\
\hline 8. P_Life & $46.69(8.62)$ & $44.77(8.43)$ & $-0.245^{\star}$ & $-0.311^{\star \star}$ & -0.148 & $0.692^{\star *}$ & -0.115 & $0.775^{\star *}$ & -0.202 & - & $-0.307^{\star \star}$ & -0.121 & 0.081 & 0.017 \\
\hline 10. D_Intrarol & $5.04(0.73)$ & $5.07(0.75)$ & 0.130 & 0.179 & $0.337^{\star}$ & -0.099 & 0.171 & 0.003 & 0.289 & -0.003 & 0.110 & - & 0.003 & 0.239 \\
\hline 11. D_Extrarol & $5.45(0.61)$ & $5.19(0.62)$ & -0.120 & 0.013 & 0.075 & 0.111 & 0.001 & 0.063 & -0.127 & 0.080 & 0.011 & 0.282 & - & 0.275 \\
\hline 12. C_Normas & $5.72(0.40)$ & $5.61(0.48)$ & -0.107 & -0.209 & 0.080 & -0.037 & -0.001 & -0.046 & 0.013 & -0.029 & -0.197 & 0.296 & $0.550^{* *}$ & - \\
\hline
\end{tabular}

Note: Below the diagonal are the correlations (Spearman) between the variables at time 1 , above at time $2 .{ }^{* *} \mathrm{p}<0.01,{ }^{*} \mathrm{p}<0.05$. 
the Routine $(1 . \bar{x}=55.0, \mathrm{sd}=8.33,2 . \bar{x}=57.49$, $\mathrm{sd}=9.20 ; \mathrm{r}=0.933 ; \mathrm{z}=$ $-2.073, \mathrm{p}=0.038 ; \mathrm{dz}=0.75$, power $=0.48)$, even though this was designed to increase optimism. Happiness in Life was increased as an effect of the strategy of Kindness, alone $(1 . \bar{x}=45.22, \mathrm{sd}=15.58,2 . \quad \bar{x}=53.52, \mathrm{sd}=15.50 ; \mathrm{r}=0.800$; $\mathrm{z}=-2.023, \mathrm{p}=0.043 ; \mathrm{dz}=0.85$, power $=0.29)$ and in combination with the $\mathrm{Re}-$ formulation of Goals $(1 . \bar{x}=56.23, \mathrm{sd}=9.57,2 . \bar{x}=59.70, \mathrm{sd}=9.92 ; \mathrm{r}=$ $0.850 ; \mathrm{z}=-2.524, \mathrm{p}=0.012 ; \mathrm{dz}=0.65$, power $=0.38)$. Pessimism in the Company and at Work was significantly reduced with the combination of the practice of Resignifying Failure and Gratitude (1. $\bar{x}=46.08, \mathrm{sd}=6.41,2 . \bar{x}=38.96$, $\mathrm{sd}=3.57 ; \mathrm{r}=0.272 ; \mathrm{z}=-2.264, \mathrm{p}=0.024 ; \mathrm{dz}=1.11$, power $=0.66$ and $1 . \bar{x}=$ 47.38, $\mathrm{sd}=7.79,2 . \quad \bar{x}=38.90, \mathrm{sd}=3.60 ; \mathrm{r}=0.327 ; \mathrm{z}=-2.226, \mathrm{p}=0.026 ; \mathrm{dz}=$ 1.14 , power $=0.68$, respectively). The control group behaved differently than expected. The people who comprised it had changes in their Pessimism with Work $(1 . \bar{x}=47.09, \mathrm{sd}=9.36,2 . \bar{x}=41.00, \mathrm{sd}=5.33 ; \mathrm{r}=0.805 ; \mathrm{z}=-2.220, \mathrm{p}$ $=0.026 ; \mathrm{dz}=1.02$, power $=0.74)$ and with Life $(1 . \bar{x}=51.65, \mathrm{sd}=8.60,2 . \bar{x}$ $=40.59, \mathrm{sd}=4.84 ; \mathrm{r}=0.254 ; \mathrm{z}=-2.692, \mathrm{p}=0.007 ; \mathrm{dz}=1.27$, power $=0.90)$ and in Optimism with the Company $(1 . \bar{x}=56.11$, sd $=5.96,2 . \bar{x}=5.47$, $\mathrm{sd}=$ $7.95 ; \mathrm{r}=0.587 ; \mathrm{z}=-2.111, \mathrm{p}=0.035 ; \mathrm{dz}=0.71$, power $=0.44)$. This may be the result of breaches of some conditions.

To ascertain the effect of gender, the analyses were replicated by separating the data for this category. With the women it was effective: Breaking the Routine improved their Happiness at Work, $(1 . \bar{x}=53.52$, sd $=10.43,2 . \quad \bar{x}=58.00$, sd $=12.14 ; \mathrm{r}=0.999 ; \mathrm{z}=-2.023, \mathrm{p}=0.043 ; \mathrm{dz}=0.84$, power $=0.45)$ and combining the Reformulation of Goals and Kindness improved their Happiness in Life (1. $\bar{x}=56.50, \mathrm{sd}=10.19,2 . \bar{x}=59.72, \mathrm{sd}=10.60 ; \mathrm{r}=0.810 ; \mathrm{z}=-2.371, \mathrm{p}=$ $0.018 ; \mathrm{dz}=0.50$, power $=0.34)$. For men the strategy of the Pencil in the Mouth improved their Happiness with Work (1. $\bar{x}=59.72$, $\mathrm{sd}=4.07,2 . \bar{x}=56.45$, $\mathrm{sd}=2.98 ; \mathrm{r}=0.700 ; \mathrm{z}=-2.023, \mathrm{p}=0.043 ; \mathrm{dz}=1.12$, power $=0.64)$, and Resignifying Failure combined with Gratitude reduced their Pessimism with Work (1. $\bar{x}=48.82, \mathrm{sd}=7.65,2 . \bar{x}=37.85, \mathrm{sd}=2.04 ; \mathrm{r}=0.186 ; \mathrm{z}=-2.032, \mathrm{p}=0.042 ;$ $\mathrm{dz}=1.45$, power $=0.82$ ). In the control group Optimism with the Company increased in the women $(1 . \bar{x}=56.11$, $\mathrm{sd}=7.22,2 . \bar{x}=51.14$, $\mathrm{sd}=8.22 ; \mathrm{r}=$ $0.898 ; \mathrm{z}=-2.236, \mathrm{p}=0.025 ; \mathrm{dz}=1.37$, power $=0.78)$.

Finally, it was verified whether there were any differences between those who improved and who did not to see if the hedonic treadmill could be limiting the effect of the practices. For this each person's scores were taken at time one and time two and then the variance of each item was reviewed. Later, in agreement with a chi-squared distribution, the likelihood that this variance was significant or not was verified. With this information it was possible to identify those people who had indeed improved to then compare them with those who had not (Table 3).

At time one the people who improved presented significantly lower levels of Happiness, Happiness at Work and Satisfaction with Life and higher levels of 
Table 3. Test of independent samples people who improve vs. people who do not improve.

\begin{tabular}{|c|c|c|c|c|}
\hline & $\mathrm{U}$ & $\mathrm{W}$ & $\mathrm{Z}$ & $\mathrm{P}$ \\
\hline H_Work1 & 718.000 & 1313.000 & -2.274 & 0.023 \\
\hline H_Life1 & 614.000 & 1209.000 & -3.104 & 0.002 \\
\hline O_Company1 & 977.000 & 1572.000 & -0.214 & 0.831 \\
\hline P_Company1 & 777.500 & 2547.500 & -1.824 & 0.068 \\
\hline O_Work1 & 952.000 & 1547.000 & -0.419 & 0.675 \\
\hline P_Work1 & 741.500 & 2511.500 & -2.121 & 0.034 \\
\hline O_Life1 & 857.500 & 1452.500 & -1.239 & 0.215 \\
\hline P_Life1 & 734.000 & 2504.000 & -2.184 & 0.029 \\
\hline S_Life1 & 518.500 & 1113.500 & -3.877 & 0.000 \\
\hline D_Intrarol1 & 143.500 & 549.500 & -0.329 & 0.742 \\
\hline D_Extrarol1 & 131.000 & 197.000 & -0.735 & 0.462 \\
\hline C_Normas1 & 152.000 & 218.000 & -0.067 & 0.946 \\
\hline H_Work2 & 773.500 & 1368.500 & -1.831 & 0.067 \\
\hline H_Life2 & 575.000 & 1170.000 & -3.138 & 0.002 \\
\hline O_Company2 & 709.000 & 1304.000 & -2.092 & 0.036 \\
\hline P_Company2 & 787.500 & 2383.500 & -1.395 & 0.163 \\
\hline O_Work2 & 789.500 & 1384.500 & -1.397 & 0.162 \\
\hline P_Work2 & 836.000 & 2432.000 & -0.990 & 0.322 \\
\hline O_Life2 & 685.000 & 1280.000 & -2.399 & 0.016 \\
\hline P_Life2 & 867.500 & 2463.500 & -0.720 & 0.471 \\
\hline S_Life2 & 575.500 & 1170.500 & -3.145 & 0.002 \\
\hline D_Intraro2 & 54.500 & 225.500 & -0.520 & 0.603 \\
\hline D_Extrarol2 & 47.000 & 218.000 & -0.978 & 0.328 \\
\hline C_Normas2 & 57.000 & 85.000 & -0.378 & 0.705 \\
\hline
\end{tabular}

Note: $\mathrm{U}=$ Mann-Whitney U; W = Wilcoxon.

Pessimism at Work and in Life than the people who did not improve. The distance was maintained, even after the improvement, in Happiness in Life and Satisfaction with Life.

\section{Discussion}

The aim of this study was to analyze the changes derived from intervention in the levels of happiness and optimism in 12 groups of employees chosen at random in 2 Colombian companies.

What was reported in the literature was confirmed in terms of the link between Optimism and Happiness [8]. This indicates that those with positive beliefs about the future and who see the favorable side of events usually derive 
greater benefit, gratification and meaning in what they do. This also happens in the work context. Optimism is considered a precursor to happiness [45], while happiness contributes to people experiencing greater satisfaction with life [46] [47]. Optimism (on its three levels) and happiness (on its two levels) were negatively associated with all types of pessimism. Similar findings are reported in the literature [34]. This indicates that it is difficult for a person to consider their future a problem if a positive idea has already been formed about it. However, the absence of negative correlations of greater magnitude indicates to us that although there are competing beliefs [48], these are not conflicting [49] [50].

There are no relations between the performance scored by the managers and people's happiness at work, life and optimism; other studies have shown the same [20]. This may be due to the relation being moderated by some variable not controlled in this study [51].

Four intervention conditions had the expected impact: Breaking the Routine, Expression of Kindness, Reformulation of Goals/Kindness and Resignification of Failure/Gratitude. This partially confirms Hypotheses H6, H2 and H7.

In terms of the differences by gender, it was found that Breaking the Routine served to improve women's Happiness with Work. Although it was expected that this would affect Optimism and not Happiness, the effect on the latter may be due to actively doing things out of the ordinary, which implies an effort to help recover from work [52]. This is more difficult for women, because they must face a double workday, which leaves them more fatigued [53] and negatively affects their health [41] [54]. The improvement can also be attributed to the suggestion that these extra-routine activities were undertaken in the company of others. The study has revealed that social interaction enhances happiness because of the increase in social support [7]. It is also known that women place greater value on social exchange than men [40].

An improvement was also seen in Happiness in Life derived from combining the strategy of the Reformulation of Goals and Kindness in women (H7). This may be due to the former contributing to the focus on important things [34] and the latter on social interaction [55]. Again, this deals with aspects that are not always equal between men and women [39].

The Pencil in the Mouth worked for the men to improve their Happiness with Work (H3). It is worth noting that this did not work to improve Happiness with Life, since the strategy focuses on a general improvement. It is possible that this is because, of the three times that the pencil had "to force" the smile, two were implemented just before or during work. Therefore, the muscles of the smile were being exercised more in a particular context [56]. What improves men and not women with this strategy may be due to it dealing with a more concrete task, which helps men identify with it [40].

Gratitude added to the Resignification of Failure helped the men reduce their Pessimism at Work (H7). It could be due to a process of cognitive reorganization that helps put failure in perspective as a learning experience [34], a condi- 
tion for psychological growth [57]. In the case of gratitude, the effect is explained by our awareness of the good things that have happened to us making it more difficult to render that compatible with negative beliefs [7].

No evidence was found to confirm Hypotheses $\mathrm{H} 1, \mathrm{H} 2$ and $\mathrm{H} 5$. It is possible that the instructions in the first two cases did not help people understand well what expressing gratitude and acting with kindness and goodness meant. In the case of H6, this dealt with a task that perhaps requires more time to see the effects, because people need to be able to see the effects of reformulating their goals.

It should be noted that, despite not confirming all the hypotheses, the two conditions that include kindness affected happiness with life. That shows that being kind has an important positive effect. This can be explained by kindness being a behavior that unites us with other human beings and promotes the development of social support derived from reciprocity [12]. This finding reinforces what has been reported in other studies [58] [59]. Improvements were even evident by requesting few acts of kindness in the week, even when it is known that if these are grouped in a single day the effect will be greater [60] [61].

Some authors point out that being kind increases happiness because it reduces the stress generated if we do not act with empathy; it avoids social sanction and increases the likelihood of receiving rewards for being kind, i.e., for selfish motives. It has also been found, however, that people can be kind for altruistic reasons [55]. From this perspective, happiness is improved by giving life and work meaning as these become connected to a greater purpose.

The general results also showed that of the nine variables that had significant changes, four were from pessimism. This may be related to the already demonstrated fact that it is much easier to bring about changes to what is bad than to what is good [45]. This argument is reinforced when it is noted that those who improved were people with lower levels of Happiness, Happiness at Work and Satisfaction with Life than those who did not improve. This may indicate that the improvements are appreciable when there is a greater margin of change and, at the same time, that those who are well could require other conditions or the same but applied with greater control if real change is desired. What was found here partly confirms the difficulty that exists, on the grounds of the hedonic treadmill, in generating changes in people's happiness and optimism levels [7].

What has been reviewed until now indicates that there are indeed applicable conditions in work contexts. Nevertheless, the analyses by gender showed that although this is not a differentiator of people's happiness [62] and optimism levels [34], it must be taken into consideration when it comes to implementing them.

It was not possible to verify the effects of the improvements in happiness and optimism on performance. The sample of managers who assessed their staff at times one and two was insufficient. Nevertheless, it became apparent from the 
beginning that there was an absence of correlations between the managers' scores and their employees' happiness and optimism, which might be a sign that we cannot wait for a direct relationship between these two realities.

This study has theoretical and practical implications. With respect to the former, it reflects the importance of testing the already proven conditions in other contexts and cultures where there is an intention to implement them. Not all the conditions work equally. Additionally, it shows that the effect of the ones that work can be different in men and women. From the practical point of view, companies can see that it is possible to intervene in the levels of people's optimism and happiness with simple, easily applied strategies. Organizations could do pilot testing with various conditions until they find the ones that best fit their culture and personnel.

\section{Conclusions and Limitations}

The study revealed the success of some conditions for improving happiness, happiness in life, optimism, optimism at work, optimism in the company and the reduction of pessimism. They are not all equally effective and differ in their effectiveness according to gender. Additionally, the intervention faces the hedonic treadmill. However, the fact that significant changes were found shows that it is viable and it makes sense for organizations to strive to bolster people's well-being.

Although the effect on performance could not be confirmed, the study shows that positive changes are possible and that this can be achieved with easily applied management conditions that can be developed without interrupting work.

This study has, however, some limitations that must be noted. The small sample size and number of people who decided to participate in the study mean that it is not known how the conditions would work on people who have the application forced on them. However, its utility could be seen in those who considered participation important. In this sense companies could work on sensitizing people before beginning plans of this type, so as to increase their willingness to be involved in the exercise. On the other hand, being an exercise outside the laboratory, it is difficult to control the real application of the conditions. It is possible that with greater control more robust results could be obtained. Many people did not develop the process at the three times and many managers did not evaluate their employees' performance before and after implementation of the conditions, which limited the scope of the study.

Nevertheless, the findings of this study show that it is viable and feasible to achieve positive changes in people in work contexts, which will have a favorable impact on their health and well-being [63]. Furthermore, thanks to this study, we understand the importance of bearing people's gender in mind when implementing conditions to increase their happiness and optimism, because their effectiveness varies according to this factor.

It is worth remembering that both people and companies benefit with the de- 
sign and implementation of effective, useful and validated conditions to improve workers' quality of life. These are conditions where everyone wins and that can be implemented easily in organizations. Thus it is shown that people's happiness and optimism can be the result of good and serious management.

\section{Acknowledgements}

The research was financed with resources given by the Centro de Investigación en Comportamiento Organizacional CINCEL (Colombia) and whit a scholarship offered by the Chilean Agency for International Cooperation for Development AGCID.

\section{Conflicts of Interest}

The authors declare no conflicts of interest regarding the publication of this paper.

\section{References}

[1] Seligman, M.E.P., Steen, T.A., Park, N. and Peterson, C. (2005) Positive Psychology Progress: Empirical Validation of Interventions. The American Psychologist, 60, 410-421.

http://www.ncbi.nlm.nih.gov/pubmed/16045394\nhttps://apps.webofknowledge.co $\mathrm{m} /$ full_record.do?product $=U A \&$ search_mode $=$ AdvancedSearch\&qid $=2 \& S I D=P 2 b u$ qYXRSSv6yAuBgKS\&page $=6 \&$ doc $=299$ https://doi.org/10.1037/0003-066X.60.5.410

[2] Meyers, C.M., van Woerkom, M. and Bakker, A.B. (2013) The Added Value of the Positive: A Literature Review of Positive Psychology Interventions in Organizations. European Journal of Work and Organizational Psychology, 22, 618-632. https://doi.org/10.1080/1359432X.2012.694689

[3] Ouweneel, E., Le Blanc, P.M. and Schaufeli, W.B. (2013) Do-It-Yourself. Career Development International, 18, 173-195. http://www.emeraldinsight.com/doi/10.1108/CDI-10-2012-0102 https://doi.org/10.1108/CDI-10-2012-0102

[4] Youssef, C.M. and Luthans, F. (2007) Positive Organizational Behavior in the Workplace: The Impact of Hope, Optimism, and Resilience. Journal of Management, 33, 774-800. https://doi.org/10.1177/0149206307305562

[5] Rodríguez-Muñoz, A. and Sanz-Vergel, A.I. (2013) Happiness and Well-Being at Work: A special Issue Introduction. Revista de Psicología del Trabajo y de las Organizaciones, 29, 95-97. https://doi.org/10.5093/tr2013a14

[6] Calderón Hernández, G., Álvarez Giraldo, C.M. and Naranjo Valencia, J.C. (2006) Gestión humana en las organizaciones un fenómeno complejo: Evolución, retos, tendencias y perspectivas de investigación. Cuadernos de Administración, 19, 225-254.

[7] Lyubomirsky, S., Dickerhoof, R., Boehm, J.K. and Sheldon, K.M. (2011) Becoming Happier Takes Both a Will and a Proper Way: An Experimental Longitudinal Intervention to Boost Well-Being. Emotion, 11, 391-402. http://doi.apa.org/getdoi.cfm?doi=10.1037/a0022575 https://doi.org/10.1037/a0022575

[8] Seligman, M. (2011) La Autentica Felicidad. ZETA, Barcelona, 440 p. 
[9] Sanín-Posada, A. and Soria, M.S. (2018) Verificación de las condiciones psicométricas del Test de Orientación en la Vida (LOT-R) aplicado en población trabajadora Colombiana. Revista Interamericana de Psicología Ocupacional, 35, 58-67. https://doi.org/10.21772/ripo.v35n2a01

[10] González-Quiñones, J.C. and Restrepo-Chavarriaga, G. (2010) Prevalencia de felicidad en ciclos vitales y relación con redes de apoyo en población colombiana. Revista de Salud Pública, 12, 228-238. https://doi.org/10.1590/S0124-00642010000200006

[11] Abbe, A., Tkach, C. and Lyubomirsky, S. (2003) The Art of Living by Dispositionally Happy People. Journal of Happiness Studies, 4, 385-404. https://doi.org/10.1023/B:JOHS.0000005769.54611.3c

[12] Tkach, C. and Lyubomirsky, S. (2006) How Do People Pursue Happiness? Relating Personality, Happiness-Increasing Strategies, and Well-Being. Journal of Happiness Studies, 7, 183-225. https://doi.org/10.1007/s10902-005-4754-1

[13] Chancellor, J., Layous, K. and Lyubomirsky, S. (2015) Recalling Positive Events at Work Makes Employees Feel Happier, Move More, but Interact Less: A 6-Week Randomized Controlled Intervention at a Japanese Workplace. Journal of Happiness Studies, 16, 871-887. https://doi.org/10.1007/s10902-014-9538-Z

[14] Meyers, M.C. and van Woerkom, M. (2016) Effects of a Strengths Intervention on General and Work-Related Well-Being: The Mediating Role of Positive Affect. Journal of Happiness Studies, 18, 671-689. https://doi.org/10.1007/s10902-016-9745-x

[15] Salanova, M., Llorens, S., Acosta, H. and Torrente, P. (2013) Positive Interventions in Positive Organizations. Terapia Psicológica, 31, 101-113. https://doi.org/10.4067/S0718-48082013000100010

[16] Sheldon, K.M. and Lyubomirsky, S. (2006) Achieving Sustainable Gains in Happiness: Change Your Actions, Not Your Circumstances. Journal of Happiness Studies, 7, 55-86. https://doi.org/10.1007/s10902-005-0868-8

[17] Easterlin, R.A. (2003) Explaining Happiness. Proceedings of the National Academy of Sciences, 100, 11176-11183. https://doi.org/10.1073/pnas.1633144100

[18] Fisher, C.D. (2010) Happiness at Work. International Journal of Management Reviews, 12, 384-412. https://doi.org/10.1111/j.1468-2370.2009.00270.x

[19] Fisher, C.D. (2003) Why Do Lay People Believe that Satisfaction and Performance Are Correlated? Possible Sources of a Commonsense Theory. Journal of Organizational Behavior, 24, 753-777. https://doi.org/10.1002/job.219

[20] Jones, M. (2006) Which Is a Better Predictor of Job Performance: Job Satisfaction or Life Satisfaction? Journal of Behavioral \& Applied Management, 8, 20-42.

[21] Wright, T.A., Larwood, L. and Denney, P.J. (2002) The Different "Faces" of Happiness-Unhappiness in Organizational Research: Emotional Exhaustion, Positive Affectivity, Negative Affectivity, and Psychological Well-Being as Correlates of Job Performance. Journal of Business and Management, 8, 109-126.

[22] Taris, T.W. and Schreurs, P.J.G. (2009) Well-Being and Organizational Performance: An Organizational-Level Test of the Happy-Productive Worker Hypothesis. Work \& Stress, 23, 120-136. https://doi.org/10.1080/02678370903072555

[23] Whitman, D.S., Van Rooy, D.L. and Viswesvaran, C. (2010) Satisfaction, Citizenship Behaviors, and Performance in Work Units: A Meta-Analysis of Collective Construct Relations. Personnel Psychology, 63, 41-81.

https://doi.org/10.1111/j.1744-6570.2009.01162.x 
[24] Zelenski, J.M., Murphy, S.A. and Jenkins, D.A. (2008) The Happy-Productive Worker Thesis Revisited. Journal of Happiness Studies, 9, 521-537. https://doi.org/10.1007/s10902-008-9087-4

[25] Wright, T.A., Cropanzano, R. and Bonett, D.G. (2007) The Moderating Role of Employee Positive Well Being on the Relation between Job Satisfaction and Job Performance. Journal of Occupational Health Psychology, 12, 93-104. https://doi.org/10.1037/1076-8998.12.2.93

[26] Crow, S.M. and Hartman, S.J. (1995) Can't Get No Satisfaction. Leadership\& Organization Development Journal, 16, 34-38. https://doi.org/10.1108/01437739510089085

[27] Wright, T. and Cropanzano, R. (2000) Psychological Well-Being and Job Satisfaction as Predictors of Job Performance. Journal of Occupational Health Psychology, 5, 84-94. https://doi.org/10.1037/1076-8998.5.1.84

[28] Wiseman, R. (2010) 59 Segundos: Piensa un poco para cambiar mucho. In: Libros, R., Ed., RBA Libros, Barcelona.

[29] Carver, C., Scheier, M. and Segerstrom, S.C. (2010) Optimism. Clinical Psychology Review, 30, 879-889. https://doi.org/10.1016/j.cpr.2010.01.006

[30] Londoño Pérez, C., Velasco Salamanca, M., Alejo Castañeda, I., Botero Soto, P. and Joliet Vanegas, I. (2014) What Makes Us Optimistic? Psychosocial Factors as Predictors of Dispositional Optimism in Young People. Terapiapsicológica, 32, 153-164.

[31] Vera-Villarroel, P., Córdova-Rubio, N. and Celis-Atenas, K. (2009) Evaluación del optimismo: un análisis preliminar del Life Orientation Test versión revisada (LOT-R) en población chilena. Universitas Psychologica, 8, 61-67.

[32] Scheier, M.F., Carver, C.S. and Bridges, M.W. (1994) Distinguishing Optimism from Neuroticism (and Trait Anxiety, Self-Mastery, and Self-Esteem): A Reevaluation of the Life Orientation Test. Journal of Personality and Social Psychology, 67, 1063-1078. https://doi.org/10.1037/0022-3514.67.6.1063

[33] Sanín-Posada, A. and Salanova, M. (2015) Análisis Psicométrico del Authentic Happiness Inventory (AHI) en población trabajadora Colombiana. Revista Interamericana de Psicologia Ocupacional, 34, 75-83. https://doi.org/10.21772/ripo.v34n2a01

[34] Avia, M. and Vázquez, C. (2011) Optimismo Inteligente. 2nd Edition, Editorial A, Madrid.

[35] Piqueras, J.A., Kuhne, W., Vera-Villarroel, P., van Straten, A. and Cuijpers, P. (2011) Happiness and Health Behaviours in Chilean College Students: A Cross-Sectional Survey. BMC Public Health, 11, 443. https://doi.org/10.1186/1471-2458-11-443

[36] Sanín-Posada, A. (2007) Estudio de diferencias en apoyo del jefe e imagen gerencial asociadas al género, nivel educativo y nivel jerárquico. Revista Interamericana de Psicología Ocupacional, 26, 38-62. http://www.redalyc.org/resumen.oa?id=219022147006

[37] Vera-Villarroel, P., Piqueras, J.A., Kuhne, W., Cuijpers, P. and van Straten, A. (2014) Differences between Men and Women in Self-Reported Body Mass Index and Its Relation to Drug Use. Substance Abuse Treatment, Prevention, and Policy, 9, 1. https://doi.org/10.1186/1747-597X-9-1

[38] Anderson, L., Van Dam, F. and Born, K. (2006) A Construct-Driven Investigation of Gender Differences in a Leadership-Role Assessment Center. Journal of Applied Psychology, 91, 555-566. https://doi.org/10.1037/0021-9010.91.3.555 
[39] Ardila, R. (1986) Psicología del hombre colombiano: Cultura y comportamiento social. Planeta.

[40] Geary, D. (2010) Male, Female. Association AP, Washington DC.

[41] Bratberg, E., Dahl, S. and Risa, A.E. (2002) The Double Burden: Do Combinations of Career and Family Obligations Increase Sickness Absence among Women? European Sociological Review, 18, 233-249. https://doi.org/10.1093/esr/18.2.233

[42] Pavot, W. and Diener, E. (1993) Review of the Satisfaction with Life Scale. Psychological Assessment, 5, 164-172. https://doi.org/10.1037/1040-3590.5.2.164

[43] Toro, F. (2010) Validación psicométrica de un conjunto de instrumentos que evalúan efectos individuales de diversos factores psicosociales. Revista Interamericana de Psicología Ocupacional, 29, 193-225.

[44] Sanín-Posada, A. (2017) Felicidad y optimismo en el trabajo. Hallazgos de investigaciones científicas. Universitat Jaume I, Castelló de la Plana.

[45] Vera-Villarroel, P., Pávez, P. and Silva, J. (2012) El rol predisponente del optimismo: Hacia un modelo etiológico del bienestar. Terapia psicológica, 30, 77-84. https://doi.org/10.4067/S0718-48082012000200008

[46] Cohn, M.A., Fredrickson, B.L., Brown, S.L., Mikels, J.A and Conway, A.M. (2009) Happiness Unpacked: Positive Emotions Increase Life Satisfaction by Building Resilience. Emotion, 9, 361. https://doi.org/10.1037/a0015952

[47] Peterson, C., Park, N. and Seligman, M.E.P. (2005) Orientations to Happiness and Life Satisfaction: The Full Life versus the Empty Life. Journal of Happiness Studies, 6, 25-41. https://doi.org/10.1007/s10902-004-1278-Z

[48] Chang, E.C., Maydeu-Olivares, A. and D’Zurilla, T.J. (1997) Optimism and Pessimism as Partially Independent Constructs: Relationship to Positive and Negative Affectivity and Psychological Well-Being. Personality and Individual Differences, 23, 433-440. https://doi.org/10.1016/S0191-8869(97)80009-8

[49] Herzberg, P.Y., Glaesmer, H. and Hoyer, J. (2006) Separating Optimism and Pessimism: A Robust Psychometric Analysis of the Revised Life Orientation Test (LOT-R). Psychological Assessment, 18, 433-438. https://doi.org/10.1037/1040-3590.18.4.433

[50] Marshall, G.N., Wortman, C.B., Kusulas, J.W., Hervig, L.K. and Vickers, R.R. (1992) Distinguishing Optimism from Pessimism: Relations to Fundamental Dimensions of Mood and Personality. Journal of Personality and Social Psychology, 62, 1067-1074. https://doi.org/10.1037/0022-3514.62.6.1067

[51] Quick, J.C. and Quick, J.D. (2004) Healthy, Happy, Productive Work: A Leadership Challenge. Organizational Dynamics, 33, 329-337.

https://doi.org/10.1016/j.orgdyn.2004.09.001

[52] Sonnentag, S. (2003) Recovery, Work Engagement, and Proactive Behavior: A New Look at the Interface between Nonwork and Work. Journal of Applied Psychology, 88, 518. https://doi.org/10.1037/0021-9010.88.3.518

[53] Dean, K. (1992) Double Burdens of Work: The Female Work and Health Paradox. Health Promotion International, 7, 17-25. https://doi.org/10.1093/heapro/7.1.17

[54] Väänänen, A., Kevin, M.V., Ala-Mursula, L., Pentti, J., Kivimäki, M. and Vahtera, J. (2005) The Double Burden of and Negative Spillover between Paid and Domestic Work: Associations with Health among Men and Women. Women \& Health, 40, 1-18. https://doi.org/10.1300/J013v40n03_01

[55] Batson, C. and Powell, A. (2003) Altruism and Prosocial Behavior. In: Millon, T. and Lerner, M., Eds., Handbook of psychology Volumen 5 Personality and Social 
Psychology. John Wiley \& Sons, Inc., Hoboken. https://doi.org/10.1002/0471264385.wei0519

[56] Ekman, P., Davidson, R.J. and Friesen, W.V. (1990) The Duchenne Smile: Emotional Expression and Brain Physiology: II. Journal of Personality and Social Psychology, 58, 342. https://doi.org/10.1037/0022-3514.58.2.342

[57] Posada, J.A.S. and Soria, M.S. (2014) Satisfacción laboral: el camino entre el crecimiento psicológico y el desempeño laboral en empresas colombianas industriales y de servicios. Universitas Psychologica, 13, 2-22. http://www.redalyc.org/resumen.oa?id=64730432009

[58] Chamorro-Premuzic, T., Bennett, E. and Furnham, A. (2007) The Happy Personality: Mediational Role of Trait Emotional Intelligence. Personality and Individual Differences, 42, 1633-1639. https://doi.org/10.1016/j.paid.2006.10.029

[59] Otake, K., Shimai, S., Tanaka-Matsumi, J., Otsui, K. and Fredrickson, B. (2006) Happy People Become Happier through Kindness: A Counting Kindnesses Intervention. Journal of Happiness Studies, 7, 361-375. https://doi.org/10.1007/s10902-005-3650-Z

[60] Buchanan, K.E. and Bardi, A. (2010) Acts of Kindness and Acts of Novelty Affect Life Satisfaction. The Journal of Social Psychology, 150, 235-237. https://doi.org/10.1080/00224540903365554

[61] Lyubomirsky, S., Sheldon, K.M. and Schkade, D. (2005) Pursuing Happiness: The Architecture of Sustainable Change. Review of General Psychology, 9, 111-131. https://doi.org/10.1037/1089-2680.9.2.111

[62] Lyubomirsky, S. (2008) The How of Happiness: A Scientific Approach to Getting the Life You Want. Penguin Press, New York, 366 p.

[63] Norrish, J.M. and Vella-Brodrick, D.A. (2008) Is the Study of Happiness a Worthy Scientific Pursuit? Social Indicators Research, 87, 393-407.

https://doi.org/10.1007/s11205-007-9147-x 